\title{
9
}

\section{Continuous Simulation Approach to Centralized Stormwater Management Design for Partial Treatment of Urbanizing Subwatersheds}

\author{
Aaron C. Farrell and Ronald B. Scheckenberger
}

Current Provincial criteria requires stormwater quality control for all new development. Traditionally, this requirement has been satisfied by the implementation of individual stormwater management facilities for each future development site. For urbanizing watersheds, the application of the currently accepted approach would result in numerous, broadly distributed facilities. Operations and maintenance required for the multiple scattered systems would be costly. Moreover, since the stormwater control systems would discharge to the existing storm sewer system, which historically has had essentially no quality control, any benefits to treating the runoff on-site would be largely reduced by the mixing of the treated runoff with untreated stormwater within the storm sewers.

The requisite stormwater quality control could alternatively be provided by centralized stormwater quality controls located at, or near, the storm sewer outlets to the receiving watercourses. This approach would reduce the operation and maintenance costs compared to multiple on-site facilities, and would provide more efficient and effective stormwater quality control. This chapter presents a design approach, applying continuous simulation, to determine the off-site storage required to provide the requisite stormwater quality control for the scattered future development areas. The Upper Ottawa Subwatershed in the City of Hamilton is used as a case study for the application of the design approach described herein.

Farrell, A. and R.B. Scheckenberger. 2005. "Continuous Simulation Approach to Centralized Stormwater Management Design for Partial Treatment of Urbanizing Subwatersheds." Journal of Water Management Modeling R223-09. doi: 10.14796/JWMM.R223-09.

(C) CHI 2005 www.chijournal.org ISSN: 2292-6062 (Formerly in Effective Modeling of Urban Water Systems. ISBN: 0-9736716-0-2) 


\subsection{Introduction}

Urbanization typically degrades water quality, during periods of rainfall discharging to receiving watercourses, producing high loadings of pollutants such as nutrients, sediments, organic compounds, and heavy metals. Without proper mitigation, urbanization may degrade water quality within the receiving watercourse, and thereby negatively affect aquatic habitat (USEPA, 1993). Stormwater management systems are required to mitigate these potential impacts in the Province of Ontario (MOE, 2003). Philosophically, stormwater quality control systems, rather than capturing all runoff during all storm events, are intended to capture the "first flush" which occurs during the more frequent storm events. These events are characterized by lower rainfall depths (i.e. generally less than $15 \mathrm{~mm}$ ), but often exhibit high rainfall intensities, sufficient to wash-off a substantial portion of the available pollutant load. As Figure 9.1 indicates, these smaller storm events represent approximately $90 \%$ of the average annual rainfall in Southern Ontario (MOEE, 1991).

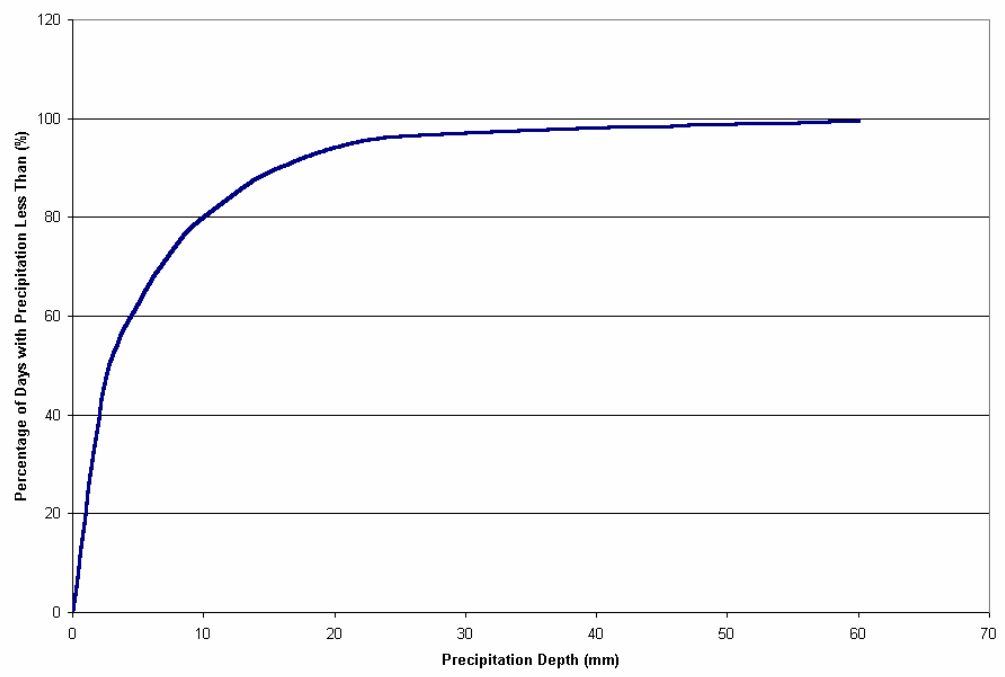

Figure 9.1 Precipitation depth duration curve (from Ministry of the Environment, June 1991).

Current Provincial standards for stormwater management (MOE, 2003) require that stormwater quality controls be provided for all new development. 
Although these are typically implemented in the form of separate systems for each new development area, it has been widely recognized that centralized stormwater management systems are superior due to increased effectiveness and decreased capital and maintenance costs. Centralized systems are almost always used in green-field developments, whereby multiple landowners, through an integrated upfront land use and infrastructure planning exercise, contribute toward the construction of a single end-of-pipe facility (e.g. wet pond, wetland or hybrid). The drainage area to these systems would consist almost entirely of new development, and the facility would discharge to an adjacent watercourse. The new community planning facilitates this process leading to the centralization of stormwater management infrastructure.

In the case of infill developments (developments within existing urban built-up areas), future development areas are often scattered throughout a partially urbanized subwatershed. The opportunities for the practical implementation of a centralized facility are therefore considered difficult. Hence, stormwater quality control systems for infill developments have generally been provided in the form of separate on-site systems, discharging to an existing storm sewer within the subwatershed as shown in Figure 9.2. The Upper Ottawa Subwatershed in the City of Hamilton is an example of an urbanizing watershed.

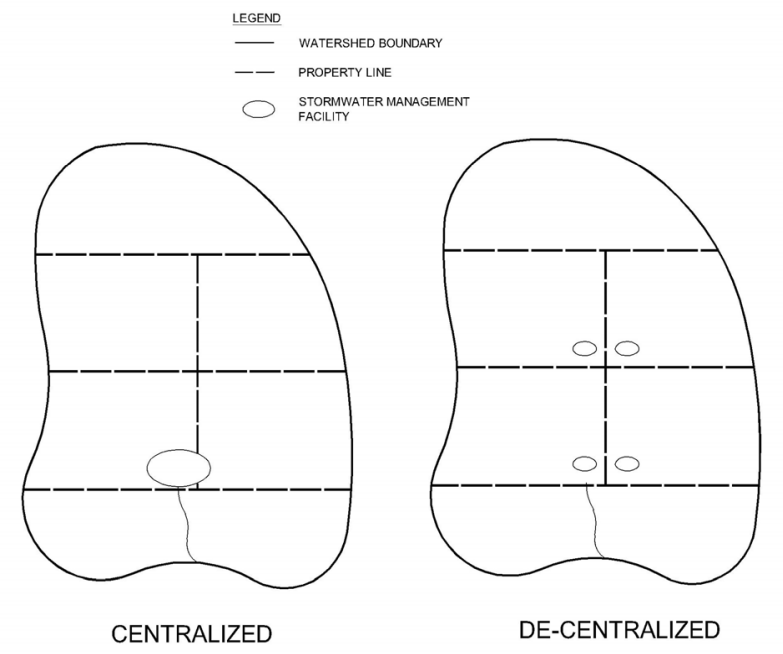

Figure 9.2 Conceptual representation of centralized and de-centralized stormwater management strategies. 


\subsubsection{Urbanizing Subwatershed Case Study—the Upper Ottawa Subwatershed}

The Upper Ottawa Subwatershed (UOS) is located in the headwaters of the Red Hill Creek Watershed (approximately $65 \mathrm{~km}^{2}$ ) within the City of Hamilton, Ontario, Canada as shown in Figure 9.3. The subwatershed measures $1356 \mathrm{ha}$, and the ultimate land use is to consist of residential, commercial, industrial, institutional, and green space dispersed throughout the subwatershed (Figure 9.4). The existing relative proportion of each land use within the UOS is summarized in Table 9.1 (based on aerial photography).

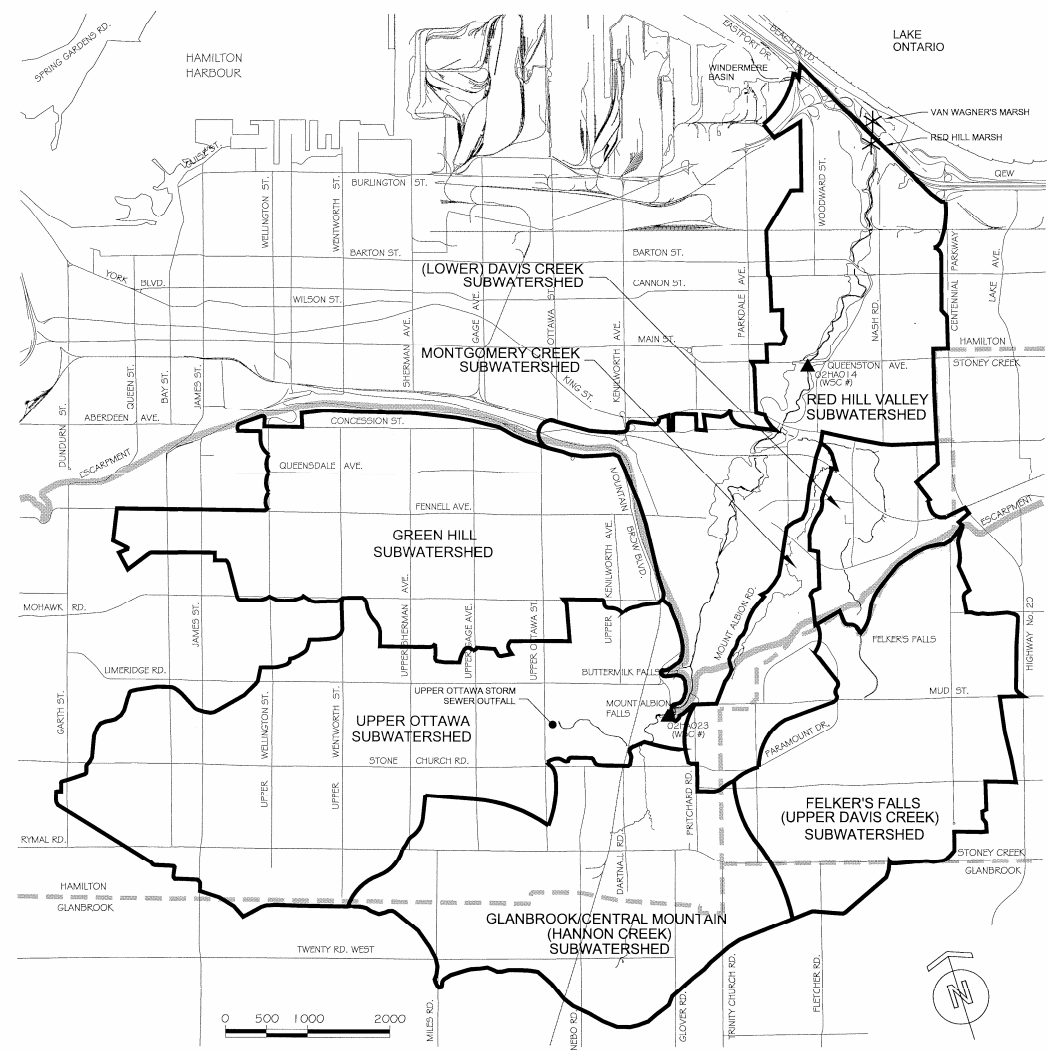

Figure 9.3 Upper Ottawa Subwatershed location plan. 


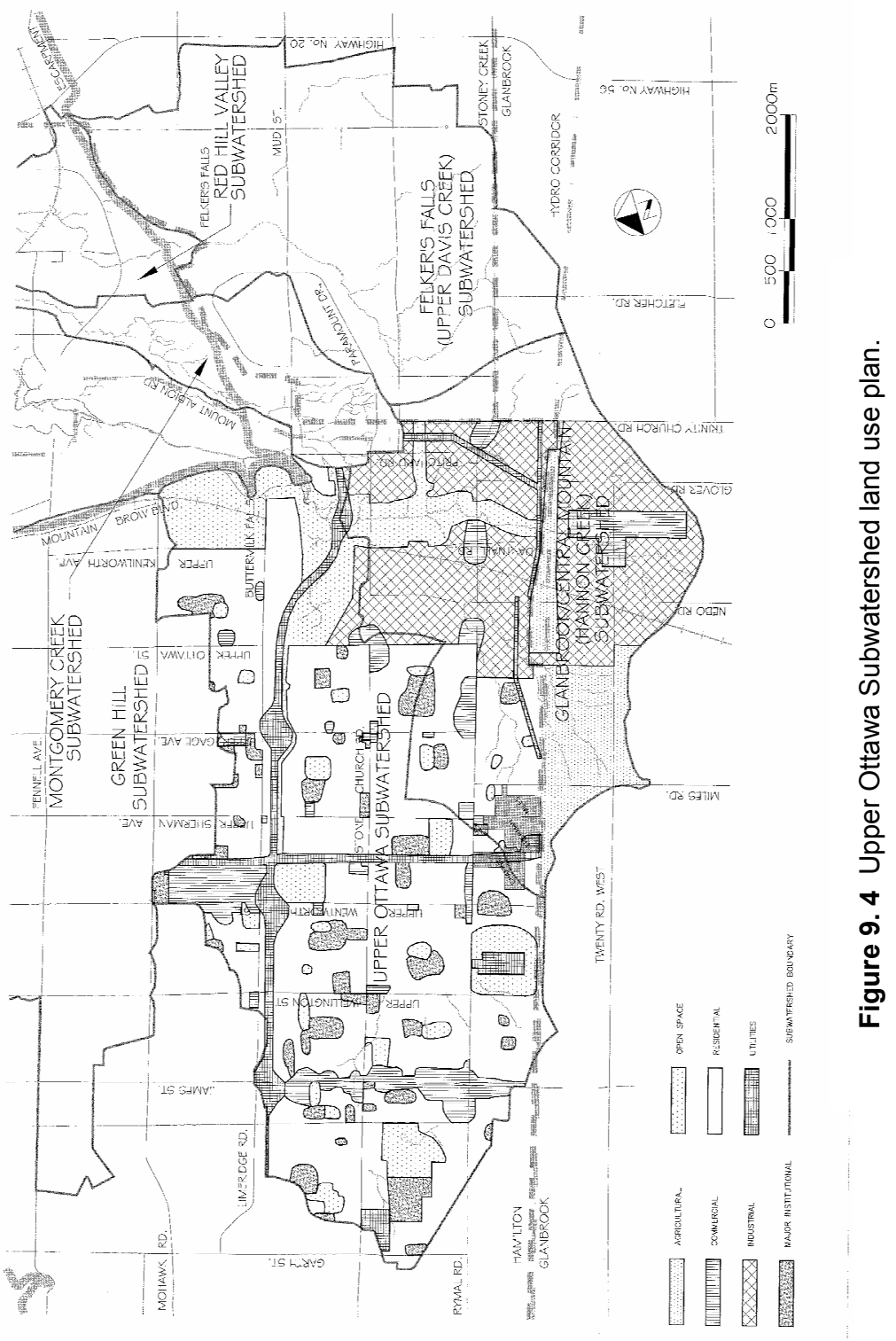


Table 9.1 Existing land use of the Upper Ottawa Subwatershed.

\begin{tabular}{cc}
\hline Land Use & Proportion of Total Land Use (\%) \\
\hline Residential & 56.5 \\
Commercial & 7.9 \\
Industrial/Utilities & 7.1 \\
Institutional & 7.8 \\
Green Space & 20.7 \\
\hline
\end{tabular}

Currently, the development within the UOS has proceeded to approximately $87 \%$ of the proposed ultimate urbanization. The remaining sites for development are spatially distributed throughout the subwatershed, with most of the future development proposed within the headwaters as shown in Figure 9.5. The UOS discharges to the Red Hill Creek at a large sewer outfall (twin $4100 \mathrm{~mm}$ x $3350 \mathrm{~mm}$ ) located on Upper Ottawa Street, adjacent to the Upper Ottawa landfill as shown in Figure 9.3. All runoff within the UOS is currently conveyed to the Red Hill Creek via the urbanized major and minor system within the subwatershed. It should be noted that historically the City has not advocated a major/minor system design approach, however design standards for the minor system have varied over the years ranging from $5 \mathrm{y}, 18 \mathrm{y}$, and up to a $50 \mathrm{y}$ return period.

Previous studies have identified that stormwater quantity controls are not required for the development areas located within the UOS, due to the relatively high capacity of the minor system, the proximity of the Red Hill Creek, and the capacity of the hydraulic structures which have been constructed across the creek downstream of the UOS (Philips Planning and Engineering Ltd., 1997). Nevertheless, stormwater quality controls are required for all future development, in accordance with current Provincial criteria (MOE, 2003).

The current practice of providing separate stormwater quality control systems for each of the future development areas dispersed within the drainage area, would result in numerous stormwater management systems. While the provision of individual stormwater quality control systems would technically satisfy the current Provincial standards, the operations and maintenance requirements of the systems, which would be the responsibility of the City of Hamilton, would be costly, and the City has experienced past difficulties in securing easements for the purpose of monitoring and/or maintaining on-site quality control systems. Furthermore, the on-site quality control systems would be anticipated to discharge to the previously contaminated minor system flows within the UOS, thereby reducing overall effectiveness. 


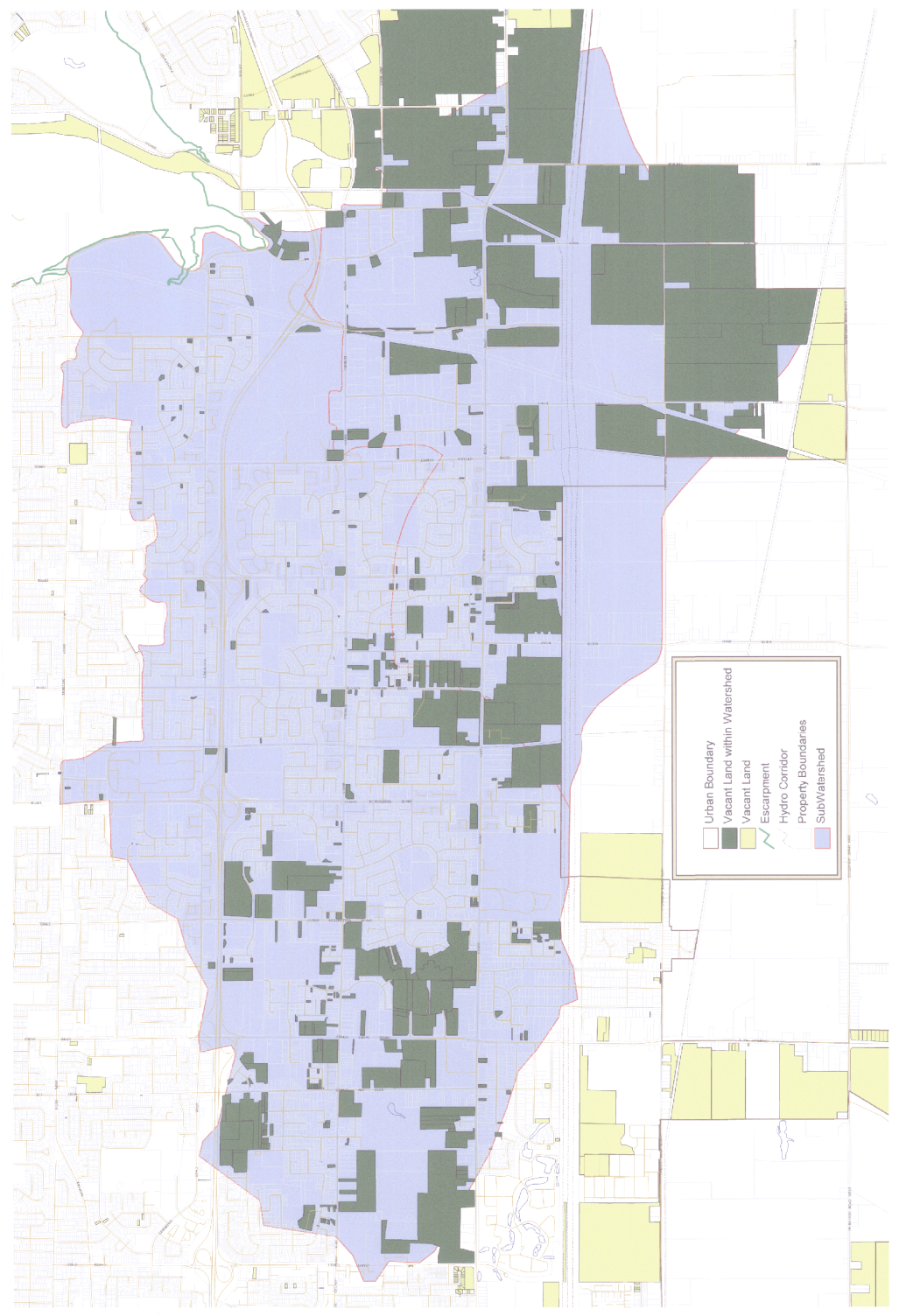

Figure 9.5 Future development areas within Upper Ottawa Subwatershed. 
As an alternative to the traditional method of providing on-site stormwater quality control, a strategy of providing the requisite stormwater quality control off-site, at a centralized location has been pursued by the City of Hamilton. The provision of stormwater quality control at a centralized location would clearly reduce the complexity of operation and maintenance compared to the traditional on-site facility option. Currently, however, there are no established criteria or methodologies for determining the appropriate sizing of off-site stormwater quality control facilities (i.e. volumes). Therefore, a method for sizing off-site facilities has been developed as part of a Class Environmental Assessment recently completed for the City of Hamilton (Philips Engineering Ltd., 2003). Numerous issues, encountered regarding the approach to providing stormwater quality control, are described further in this chapter, along with a comparison of the standards and concepts associated with current practice for stormwater quality system design.

\subsection{Conventional Stormwater Quality Control Systems: On-Site Facilities}

The current criteria for quality control of storm runoff are provided in the Stormwater Management Planning and Design Manual (Ontario Ministry of the Environment, 2003). Alternative techniques for the provision of stormwater quality control, which are currently endorsed by the Ministry of the Environment, include:

- soakaway pits,

- infiltration trenches,

- grassed swales,

- pervious pipe systems,

- pervious catchbasins,

- vegetated filter strips,

- buffer strips,

- oil/grit separators,

- wet ponds,

- wetlands, and

- hybrids.

The selection of the appropriate system for the provision of stormwater quality control is dependent upon several factors, including the sensitivity of the receiving system, land use, spatial constraints (i.e. available footprint), and the drainage area to the facility. In general, the current Ministry standards and 
criteria could be used to develop stormwater quality control systems for development areas measuring as little as 0.1 ha and as much as 100 ha or greater. The criteria, however, are generally understood to be applicable only in circumstances where the entire urbanized drainage area to the facility would require stormwater quality control.

Stormwater quality control systems in Ontario are required to provide a specified long-term level of quality control which is a function of the quality and sensitivity of aquatic habitat within the receiving watercourse. Level 1 or "Enhanced" habitat protection is required for Type 1 habitats as defined by the Ontario Ministry of Natural Resources (MNR), which include:

- spawning areas for species with stringent spawning requirements,

- essential rearing areas,

- highly productive feeding areas (wetlands),

- refuges,

- constricted migration routes,

- habitats supporting endangered, threatened or vulnerable species,

- groundwater recharge areas in coldwater streams.

Level 2 or "Normal" habitat protection is required for Type 2 habitats as defined by the MNR, which include:

- feeding areas, particularly for adult fish,

- areas of unspecialized spawning habitat, and

- pool-riffle-run complexes that occur along much of a watercourse.

Level 3 or "Basic" habitat protection is required for Type 3 habitats as defined by the MNR, which include:

- municipal drains,

- watercourses highly altered by urbanized or agricultural practices,

- portions of waterbodies hardened (concrete lined) and polluted, artificial drainage swales.

Stormwater quality control facilities are currently evaluated on the basis of long-term Total Suspended Solids (TSS) removal, in order to determine the performance of stormwater quality control and the associated level of habitat protection (MOE, 2003). Table 9.2 summarizes the current standards for habitat protection and TSS removal.

End-of-pipe stormwater management systems, such as wet ponds, wetlands, or hybrids, are the most common means of providing stormwater quality control for drainage areas greater than 5 ha. Wet facilities for stormwater quality control consist of a permanent pool and an extended detention storage volume. The permanent pool volume serves to trap sediments, reduce inlet velocities and remove pollutants (Schueler et. al., 
1992). The extended detention volume temporarily detains the runoff ( $24 \mathrm{~h}$ or greater) in order that the sediment may settle out of the runoff and be deposited within the facility (Schueler et. al., 1992).

TABLE 9.2 Summary of current standards of protection levels and associated TSS removal rates within the province of Ontario.

\begin{tabular}{cc}
\hline Protection Level & Long-Term TSS Removal Efficiency (\%) \\
\hline Enhanced/Level 1 Habitat Protection & 80 \\
Normal/Level 2 Habitat Protection & 70 \\
Basic/Level 3 Habitat Protection & 60 \\
\hline
\end{tabular}

The current Provincial standards for sizing stormwater quality control facilities specify a standard unitary extended detention volume of $40 \mathrm{~m}^{3} / \mathrm{ha}$ drainage area and a drawdown time of $24 \mathrm{~h}$ or greater regardless of land use; the permanent pool volume is determined based upon the type of facility, the requisite level of habitat protection, and impervious coverage of the drainage area to the facility, as indicated in Table 9.3.

TABLE 9.3 Total water quality storage requirements from MOE, 2003 - permanent pool and extended detention $\left(\mathrm{m}^{3} / \mathrm{ha}\right)$.

\begin{tabular}{llcccc}
\hline \multicolumn{1}{c}{ Protection Level } & SWMP Type & \multicolumn{4}{c}{ Impervious Level (\%) } \\
& & 35 & 55 & 70 & 85 \\
\hline Level 1 & Wetland & 80 & 105 & 120 & 140 \\
(80\% long-term TSS removal) & Wet Pond & 140 & 190 & 225 & 250 \\
& Hybrid & 110 & 150 & 175 & 195 \\
Level 2 & Wetland & 60 & 70 & 80 & 90 \\
(70\% long-term TSS removal) & Wet Pond & 90 & 110 & 130 & 150 \\
& Hybrid & 75 & 90 & 105 & 120 \\
Level 3 & Wetland & 60 & 60 & 60 & 60 \\
(60\% long-term TSS removal) & Wet Pond & 60 & 75 & 85 & 95 \\
& Hybrid & 60 & 70 & 75 & 80 \\
\hline Note: Values provided include $40 \mathrm{~m}^{3}$ /ha extended detention
\end{tabular}

Note: Values provided include $40 \mathrm{~m}^{3} / \mathrm{ha}$ extended detention storage.

Sizing of On-Site Facilities for the Upper Ottawa Subwatershed

The total storage requirements for future development within the UOS have been estimated based upon the MOE criteria provided in Table 9.3. Wet pond facilities have been assumed for the calculation, since the facilities would discharge to the storm sewers, and the habitat benefits usually afforded by wetlands, would not be required. Level 2 habitat protection (i.e. $70 \%$ longterm TSS removal) has been considered appropriate due to the largely urban 
land use within the Red Hill Creek Watershed, as well as the aquatic habitat which has been previously observed within the Red Hill Creek (Portt, 1997). The results are presented in Table 9.4.

Table 9.4 Total storage volumes $\left(\mathrm{m}^{3}\right)$ required for on-site stormwater management for new development within Upper Ottawa Subwatershed.

\begin{tabular}{ccc}
\hline New Development Area (ha) & Extended Detention Volume & Permanent Pool Volume \\
\hline 170 & 6,800 & 11,800 \\
\hline
\end{tabular}

While on-site stormwater management systems could be constructed for each development, in order to achieve the requisite stormwater quality control, numerous systems would be required. As such, an alternative strategy for the provision of stormwater quality control of future development areas has been considered in the form of a "centralized" facility(s) at the outlet of the subwatershed.

\subsection{Off-Site Stormwater Quality Control}

An alternative to providing stormwater quality control on-site for each individual infill development, would be to provide stormwater quality treatment at a facility(s) constructed adjacent to or near the receiving watercourse (i.e. off-site in a centralized location). Under this approach, the off-site facility would receive runoff from a significantly larger drainage area compared to the conventional on-site facilities (i.e. 1356 ha versus less than $100 \mathrm{ha}$ ). Since the majority of the drainage area within the UOS is currently urbanized without stormwater quality controls, a facility constructed downstream of the subwatershed outlet would also provide a level of stormwater quality treatment for existing developments.

Intuitively, it would be expected that the extended detention storage for an off-site facility would be less than that required for on-site treatment, due to the significant amount and higher frequency of existing untreated runoff and pollutant load which would be routed through the proposed off-site facility. Furthermore, this approach, clearly, would mitigate the onerous operations and maintenance requirements which would be associated with the provision of separate on-site facilities for stormwater quality control at each development. However, there is currently no standard MOE procedure for the design of an end-of-pipe system, to treat only a portion of the total runoff 
from a drainage area the size of the UOS. Consequently, an alternative methodology was required in order to quantify the extended detention and permanent pool requirement for the centralized off-site facility alternative.

\subsubsection{Hydrologic Modeling}

As previously indicated, the off-site stormwater management facility alternative would be required to treat only a portion of the average annual runoff from the UOS. Hydrologic modeling using continuous simulation has been used as the method for determining the extended detention volume requirements of the off-site stormwater management facilities. The most current hydrologic analyses for the Red Hill Creek Watershed, including the UOS have been completed as part of the Red Hill Creek Watershed Plan (Philips Planning and Engineering Ltd., 1997) using the Hydrologic Simulation Program-Fortran (HSP-F) hydrologic model. This model has been calibrated at two locations using ten years of observed flow data (Figure 9.3). The calibrated parameters for the pervious and impervious areas (directly connected) within the UOS subcatchments are summarized in Table 9.5; the location of the subcatchments within the UOS are depicted in Figure 9.6. The hydrologic analyses which have been completed for the Red Hill Creek Watershed Plan have applied continuous simulation methodology using 34 y $(1962$ - 1995) of meteorologic data (i.e. hourly precipitation, hourly wind movement, hourly dewpoint, hourly solar radiation, daily evaporation, and daily temperature).

Table 9.5 Subcatchment parameterization for HSP-F model of Upper Ottawa Subwatershed.

\begin{tabular}{|c|c|c|c|c|c|c|c|}
\hline \multirow{2}{*}{$\begin{array}{c}\text { Sub- } \\
\text { catchment }\end{array}$} & \multirow{2}{*}{$\begin{array}{l}\text { Area } \\
\text { (ha) }\end{array}$} & \multicolumn{6}{|c|}{ Pervious Areas } \\
\hline & & $\begin{array}{c}\text { LZSN } \\
(\mathrm{mm})\end{array}$ & $\begin{array}{l}\text { UZSN } \\
(\mathrm{mm})\end{array}$ & $\begin{array}{l}\text { INFILT } \\
(\mathrm{mm} / \mathrm{hr})\end{array}$ & $\begin{array}{c}\text { CEPSC } \\
(\mathrm{mm})\end{array}$ & NSUR & $\begin{array}{c}\text { AGWRC } \\
\left(\text { day }^{-1}\right)\end{array}$ \\
\hline 1019 & 215 & 75.0 & 12.0 & 4.2 & 2.5 & 0.2 & 0.97 \\
\hline 1020 & 361 & 142.5 & 12.0 & 3.5 & 2.5 & 0.2 & 0.97 \\
\hline \multirow[t]{6}{*}{1021} & 780 & 150.0 & 12.0 & 3.0 & 2.5 & 0.2 & 0.97 \\
\hline & & Sub- & Area & \multicolumn{2}{|c|}{ Impervious Areas } & & \\
\hline & & catchment & (ha) & NSUR & $\begin{array}{c}\text { RETSC } \\
(\mathrm{mm})\end{array}$ & & \\
\hline & & 1019 & 215 & 0.012 & 1.25 & & \\
\hline & & 1020 & 361 & 0.012 & 1.25 & & \\
\hline & & 1021 & 780 & 0.012 & 1.25 & & \\
\hline
\end{tabular}


where:

LZSN $=$ nominal lower zone storage,

UZSN = nominal upper zone storage,

INFILT = infiltration,

CEPSC $=$ interception storage for pervious areas,

NSUR $=$ roughness coefficient,

AGWRC = groundwater recession constant, and

RETSC $=$ retention storage for impervious areas.

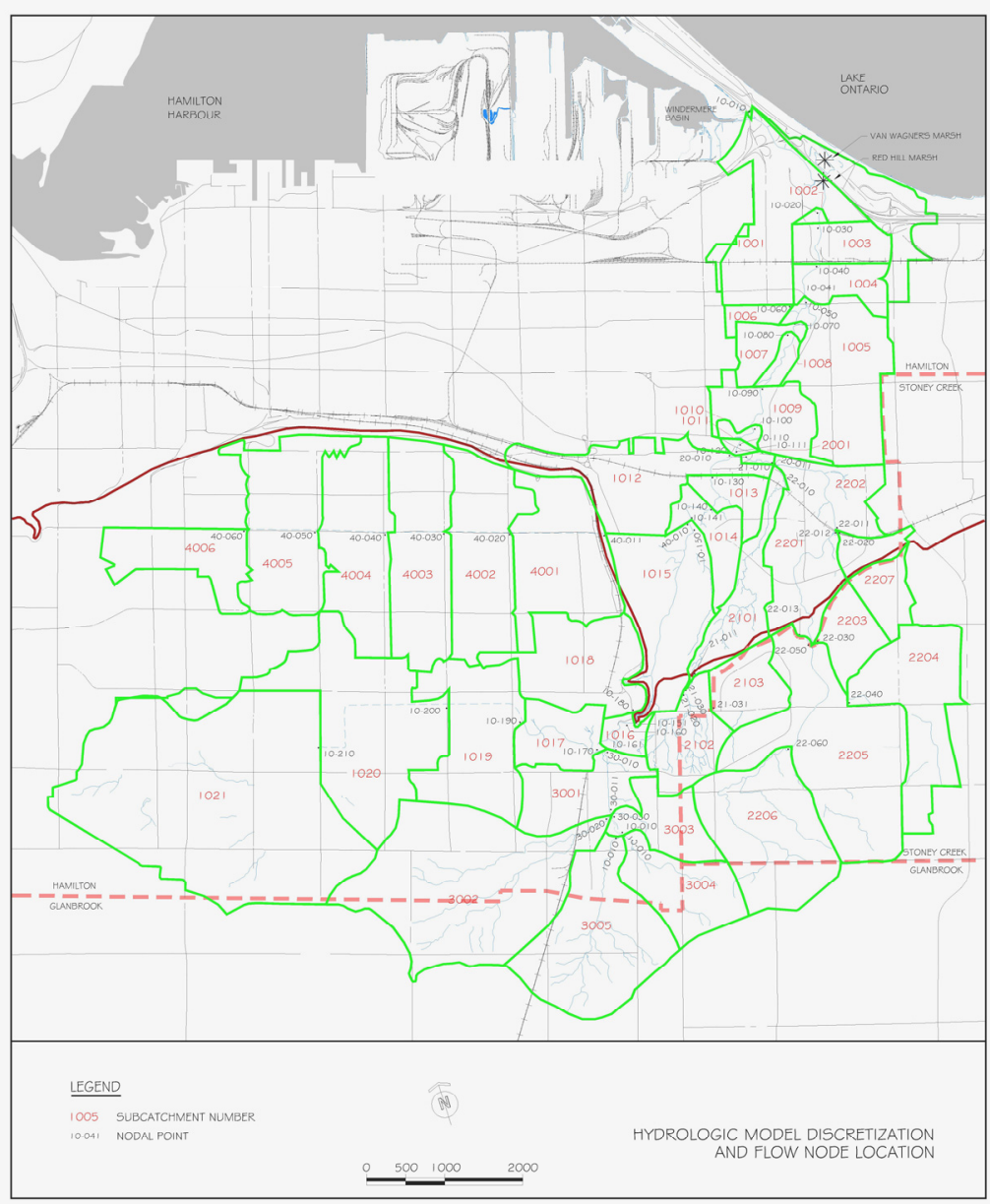

Figure 9. 6 Subcatchment location plan for hydrologic analysis. 
The impervious coverage within the UOS has been revised from the 1996 land use conditions, simulated for the Watershed Plan, in order to reflect the baseline (i.e. 2002) land use conditions within the UOS for the current assessment. Under future land use conditions, the impervious coverage within the UOS would increase as a result of the planned development in accordance with the Official Plan of the City of Hamilton. Table 9.6 summarizes the baseline and future impervious coverages for each subcatchment in the UOS.

Table 9.6 Impervious coverages for subcatchments within Upper Ottawa Subwatershed (\%).

\begin{tabular}{ccc}
\hline Subcatchment & $\begin{array}{c}\text { Baseline (2002) Impervious } \\
\text { Coverage }\end{array}$ & $\begin{array}{c}\text { Future Impervious } \\
\text { Coverage }\end{array}$ \\
\hline 1019 & 48.3 & 49.1 \\
1020 & 44.5 & 45.0 \\
1021 & 37.0 & 48.4 \\
\hline Total For Upper Ottawa & 40.8 & 47.6 \\
Subwatershed & & \\
\hline
\end{tabular}

The hydrologic model schematic for the evaluation of off-site stormwater management has been developed such that the surface runoff from the impervious areas, and the surface runoff and interflow from the pervious areas have been simulated; these portions of the runoff represent the subcatchment response during stormwater quality control events.

\subsubsection{Stormwater Management Facility Assessment}

Current Provincial criteria equate the level of habitat protection with the longterm average TSS removal provided by the stormwater management facility. The TSS removal within the facility would occur as discrete settling of the soil particles, and is influenced by the extended detention storage within the facility. The off-site stormwater management facility would be required to provide a level of TSS removal equivalent to that which would be achieved using separate on-site facilities, and would therefore be required to capture only a portion of the total runoff to the facility within the extended detention cell.

Hydrologic analyses using continuous simulation have been completed in order to establish and evaluate the relationships between:

1. the extended detention storage within the facility,

2. the impervious coverage of the drainage area to the facility, and 
3. the long-term average runoff volume which would be captured within the extended detention storage and would therefore receive stormwater quality treatment.

As indicated in Table 9.3 above, the current Provincial criteria define the volume requirements for stormwater management facilities based upon varying levels of impervious coverage within the drainage area. In order to maintain a degree of comparability between the current Provincial criteria for on-site facilities and the criteria developed for sizing off-site facilities to provide partial treatment of storm runoff, separate 34-y continuous simulations have been completed for the UOS at impervious coverages of $5 \%$, $15 \%, 35 \%, 55 \%$, and $75 \%$. In order to determine the relationship between variations in impervious coverage and the extended detention volume within the facility, the runoff has been routed through idealized stormwater management facilities providing unitary volumes of $2.5 \mathrm{~m}^{3} / \mathrm{ha}, 5 \mathrm{~m}^{3} / \mathrm{ha}$, $10 \mathrm{~m}^{3} / \mathrm{ha}, 25 \mathrm{~m}^{3} / \mathrm{ha}, 50 \mathrm{~m}^{3} / \mathrm{ha}$, and $75 \mathrm{~m}^{3} / \mathrm{ha}$ for each of the impervious coverage scenarios considered. The extended detention discharge from each facility has been calculated based upon the total facility volume and assuming 24-h extended detention discharge, which is consistent with the current Provincial criteria for extended detention storage.

During a quality storm event, the interflow component of the runoff from an urban subcatchment would be essentially "clean", whereas the surface component would carry the contaminants; therefore the surface component represents that portion of the total runoff from an urban subcatchment requiring stormwater quality control. For this reason, only the surface runoff has been routed through the facility for this assessment. Total runoff volumes from the UOS, as well as the total treated volume at the outlet of the stormwater management facilities (i.e. the total volume of runoff captured by the stormwater management facility) have been calculated based upon the simulated flows for the 34-y continuous simulation (Table 9.7).

Table 9.7 Total volumes for 34 y continuous simulation $\left(10^{6} \mathrm{~m}^{3}, \mathrm{Mm}^{3}\right)$.

\begin{tabular}{cccccccc}
\hline \multirow{2}{*}{$\begin{array}{c}\text { Imp. } \\
\text { Cover } \\
(\%)\end{array}$} & $\begin{array}{c}\text { Surface \& } \\
\text { Interflow } \\
\text { Volume }\end{array}$ & $2.5 \mathrm{~m}^{3} / \mathrm{ha}$ & $5 \mathrm{~m}^{3} / \mathrm{ha}$ & $15 \mathrm{~m}^{3} / \mathrm{ha}$ & $25 \mathrm{~m}^{3} / \mathrm{ha}$ & $55 \mathrm{~m}^{3} / \mathrm{ha}$ & $75 \mathrm{~m}^{3} / \mathrm{ha}$ \\
\hline 5 & 39.3 & 9.3 & 13.4 & 16.4 & 17.5 & 18.0 & 18.1 \\
15 & 69.6 & 12.5 & 21.0 & 32.3 & 45.6 & 49.4 & 50.1 \\
35 & 130.1 & 14.0 & 25.6 & 44.0 & 77.4 & 101.3 & 109.6 \\
55 & 190.7 & 14.7 & 27.3 & 49.1 & 94.2 & 135.9 & 156.6 \\
75 & 251.2 & 15.2 & 28.3 & 52.0 & 104.7 & 159.8 & 192.3 \\
\hline
\end{tabular}


The volume discharged from the stormwater management facility represents the portion of the total storm runoff which would be treated by the stormwater management facility (i.e. Total Treated Volume). Using the results from Table 9.7, the fraction of runoff which would be treated for stormwater quality control has been calculated to determine the percentage of runoff which would be treated. The results are presented graphically in Figure 9.7.

The results in Table 9.7 and Figure 9.7 indicate the following trends:

- For a given level of impervious coverage, the volume of surface runoff treated by the stormwater management facility would increase as the volume of the facility increases.

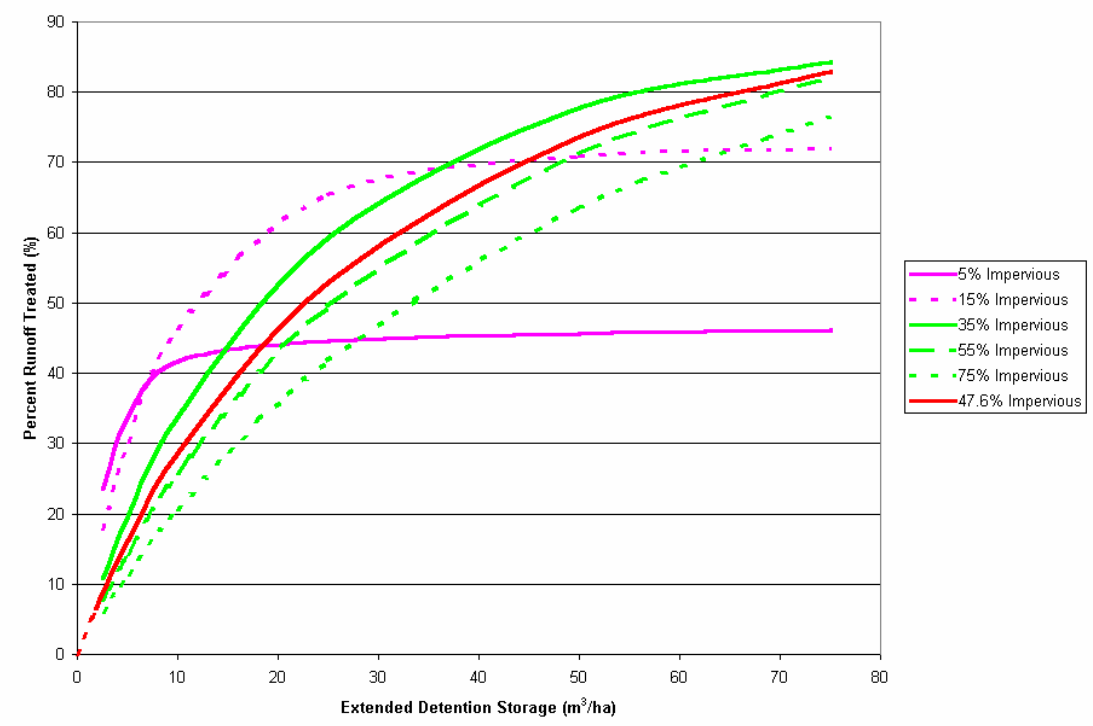

Figure $9.7 \%$ runoff treated versus extended detention volume; interpolated relationship for $47.6 \%$ impervious coverage.

- For a given unitary volume for a stormwater management facility, the volume of runoff captured, and therefore the volume of runoff treated, would increase with increasing impervious coverage of the drainage area. However, for a given unitary volume for a stormwater management facility, the relative portion of total runoff (i.e. percentage of total runoff which would be treated) 
does not show a consistent trend of either increasing or decreasing with increasing impervious coverage.

- For drainage areas of $5 \%$ impervious coverage, the portion of runoff treated reaches an optimum level (i.e. becomes asymptotic) at approximately $42 \%$, corresponding to a unitary extended detention volume of $10 \mathrm{~m}^{3} / \mathrm{ha}$. At this storage level, nearly all of the contaminated surface runoff would be captured, and any increases to the extended detention storage would not provide any appreciable benefit (i.e. increase) to the portion of runoff treated.

- For drainage areas of $15 \%$ impervious coverage, the portion of runoff treated reaches an optimum level (i.e. becomes asymptotic) at approximately $70 \%$, corresponding to a unitary extended detention volume of $35 \mathrm{~m}^{3} / \mathrm{ha}$.

- For drainage areas of $35 \%$ or more, the portion of runoff treated does not reach an optimum level for the range of facility volumes considered.

The above observations are consistent with the intuitive expectations regarding the relationship between impervious coverage, facility size and volume of runoff treated. The observed asymptotic relationships observed for the lower impervious coverages (i.e. 5\% and 15\%) suggest that the application of centralized stormwater management for partial treatment of includes limitations in terms of the extent of treatment available for the lower levels of impervious coverage.

\subsubsection{Stormwater Management Requirements for Upper Ottawa Subwatershed}

The results of the foregoing analyses have been used in order to determine the requisite extended detention storage for an off-site facility to treat the runoff from the UOS. The off-site stormwater quality facility for the UOS has been recommended to be constructed as an on-line wet pond or wetland located downstream of the UOS outlet at the Upper Ottawa storm sewer outfall. Under this design, the baseflows within the reach of the Red Hill Creek between the Subwatershed outlet and the facility would be conveyed through the pond; by comparison, an off-line facility design would include a bypass channel which would convey the baseflows around the facility during lowflow periods. Therefore, the total runoff to the facility, under this strategy, would include groundwater discharge. 
In accordance with current Provincial criteria, the facility would be required to treat only the runoff from the new development. This would be equal to the fraction of runoff from new development areas compared to the total runoff from the future subwatershed. Table 9.8 presents the total runoff volumes for the UOS for the $34 \mathrm{y}$ continuous simulation under existing and future land use conditions.

Based upon the results provided in Table 9.8, the on-line facility would be required provide long-term treatment for $14.37 \mathrm{Mm}^{3}$ of $216.04 \mathrm{Mm}^{3}$ of runoff to the facility (i.e. treatment of $6.6 \%$ of total runoff to the facility).

Table 9.8 Summary of runoff volume from Upper Ottawa Subwatershed for 34 year continuous simulation $\left(\mathrm{Mm}^{3}\right)$.

\begin{tabular}{cc}
\hline Source & Volume \\
\hline Existing Land Use Conditions & 201.67 \\
Future Land Use Conditions & 216.04 \\
Difference & 14.37 \\
\hline
\end{tabular}

Based upon the foregoing assessment, as well as the Subwatershed characteristics under future land use conditions, the off-site stormwater quality control facility would be required to treat $6.6 \%$ of runoff from a drainage area at $47.6 \%$ impervious coverage (i.e. the future impervious coverage for the UOS). The requisite extended detention volume has been determined using the results provided above in Figure 9.7. Linear interpolation of the results has been completed in order to determine the percentage treatment relationship corresponding to a $47.6 \%$ impervious coverage area (Figure 9.7), and linear extrapolation has been completed in order to determine the requisite volume to treat $6.6 \%$ of the runoff (Figure 9.7). The results indicate that a unitary extended detention storage volume of $1.9 \mathrm{~m}^{3} / \mathrm{ha}$ would be required to treat $6.6 \%$ of the runoff from a $47.6 \%$ impervious coverage drainage area. The UOS measures 1356 ha. Therefore, the extended detention requirement for an off-site stormwater management facility would be $1.9 \mathrm{~m}^{3} /$ ha $\times 1356 \mathrm{ha}=2,580 \mathrm{~m}^{3}$.

\subsection{Discussion}

While the analyses documented herein have provided a method for determining the extended detention volume requirements for off-site facilities, in order to treat a portion of storm runoff, little information is provided within 
the available literature to suggest an appropriate method of sizing the permanent pool volume under the same strategy. In addition to serving as a containment cell for the suspended solids, which are removed from the treated runoff, it is recognized that the permanent pool volume also provides biological treatment for the runoff. Theoretically, when the untreated stormwater enters the facility, it displaces the treated water within the permanent pool; the biological treatment would be provided for the stormwater within the subsequent inter-event period. For sizing the permanent pool requirements for the off-site stormwater management facility, the criteria of providing a permanent pool volume equivalent to the total permanent pool required for on-site facilities has been applied.

The volume requirements for the on-site and off-site stormwater management alternatives, as determined in the previous analyses, are summarized in Table 9.9. While wet pond facilities would be most appropriate for the on-site alternative, the off-site facility has been proposed to consist of either a wet pond or wetland facility. The results in Table 9.9 indicate that the implementation of the off-site stormwater management facility would reduce the extended detention storage requirements by $58.5 \%$ compared to the implementation of the traditional on-site alternative. The total storage requirements would be reduced by between $21.4 \%$ and $57.8 \%$, depending upon the type of facility constructed.

Table 9.9 Summary of volume requirements for on-site and off-site stormwater management facility alternatives $\left(\mathrm{m}^{3}\right)$.

\begin{tabular}{lccc}
\hline $\begin{array}{c}\text { VOLUME } \\
\text { COMPONENT }\end{array}$ & $\begin{array}{c}\text { On-Site Stormwater } \\
\text { Management } \\
\text { (Wet Pond Facilities) }\end{array}$ & $\begin{array}{c}\text { Off-Site Stormwater } \\
\text { Management } \\
\text { Wet Pond Facility }\end{array}$ & $\begin{array}{c}\text { Off-Site Stormwater } \\
\text { Management } \\
\text { Wetland Facility }\end{array}$ \\
\hline Extended Detention & 6,800 & 2,820 & 2,820 \\
Permanent Pool & 11,800 & 11,800 & 5,020 \\
Total Storage & 18,600 & 14,620 & 7,840 \\
\hline
\end{tabular}

The total storage requirement is dependent upon the permanent pool storage required. A review of standards for the determination of permanent pool storage, other than those specified by the Ontario Ministry of the Environment, has indicated that, in certain jurisdictions, the requisite permanent pool volume is calculated based upon specified ratios of permanent pool volume to extended detention volume. Table 9.10 compares various design ratios of permanent pool volume to extended detention volume. 
Table 9.10 Summary of permanent pool volume to extended detention storage volume ratios.

\begin{tabular}{lcc}
\hline \multicolumn{1}{c}{ Source } & Wet Pond & Wetland \\
\hline MOEE, March 2003 ${ }^{1 .}$ & $1.7: 1$ & $0.7: 1$ \\
Prince George County, May 2000 & $3: 1$ & - \\
CASQA, January 2003 & - & $2: 1$ \\
Schueler, 1992 & - & $1: 1$ \\
\hline
\end{tabular}

Note: ${ }^{1 .}$ The permanent pool volume to extended detention volume ratio has been calculated based upon the application of the MOEE criteria for on-site extended detention and permanent pool volume to provide Normal (Level 2) habitat protection for the Upper Ottawa Subwatershed.

The proposed extended detention and permanent pool volumes for the offsite stormwater management facilities would provide permanent pool volume to extended detention volume ratios of 4.2:1 and 1.8:1 for the wet pond and wetland facilities respectively, which would generally meet or exceed the ratio requirements, as endorsed within various jurisdictions.

\subsection{Conclusions}

The provision of centralized stormwater management systems for stormwater quality control of runoff would reduce the number of facilities within an urbanized subwatershed, compared to the practice of providing separate systems for each new development; the reduction in number would provide a benefit in terms of reduced operations and maintenance requirements and costs for the municipality. Additional benefits would be realized in terms of reduced construction costs due to the lower volume requirements. The construction of a centralized system on publicly-owned lands would also provide a further advantage in terms of improved development potential for the future development sites, since no development area would be lost due to the provision of a stormwater quality control system or maintenance easement.

This approach to the sizing of off-site stormwater quality control facilities has applied a continuous simulation methodology for the determination of extended detention storage requirements. This approach has validated the proposed extended detention volume for an off-site facility to treat runoff from the UOS within the City of Hamilton, which is consistent with the "intuitive" design concepts of reduced storage volumes compared to the traditional on-site alternative. Moreover, the application of the continuous simulation methodology has provided a site-specific approach for evaluating 
the requirements for off-site facilities, which would account for the hydrologic characteristics specific to the study area.

Future study should be completed in order to verify the results of the assessment approach using event-based and long-term TSS removal. This assessment would, ideally, account for varying concentrations of contaminants associated with varying inter-event periods and land use conditions, as well as higher loading frequencies within the rising limb of the hydrograph as per the first-flush concept. Furthermore, these studies should include assessments of the limitations of this strategy for drainage areas of lower impervious coverage (i.e. 5\% and 15\% imperviousness).

Additional research and information is required to provide clear guidance for the sizing of permanent pool storage at an off-site facility. This would require a better understanding of the processes within end-of-pipe facilities (i.e. primary sediment removal, biological processes, etc.) in order to evaluate the performance of these systems beyond a reduction in TSS. This assessment would likely be required to account for potential impacts of different vegetation species as well as the type of facility (i.e. wet pond, wetland, or hybrid).

Finally, additional research should be completed in order to develop a methodology for the sizing of extended detention and permanent pool storage volumes for off-line facilities as opposed to the on-line alternative evaluated herein. This assessment would likely require the incorporation of a split-flow element within the continuous simulation in order to incorporate the portion of runoff which would be diverted around the facility via the bypass channel during quality storm events.

\section{References}

California Stormwater Quality Association (CASQA). January 2003. California Stormwater BMP Handbook, TC-21.

Ontario Ministry of the Environment (MOE). March 2003. Stormwater Management Planning and Design Manual.

Ontario Ministry of the Environment and Energy (MOEE). June 1991. Stormwater Quality Best Management Practices.

Philips Engineering Ltd. September 2003. Mountain Brow Boulevard and Central Mountain Stormwater Management Class Environmental Assessment.

Philips Planning and Engineering Limited. November 1997. Red Hill Creek Watershed Plan Surface Water Report.

Portt, C. and Associates. 1997. Red Hill Creek Watershed Study Fisheries Phase 1: Background Inventory. 
Prince George's County Department of Environmental Resources. May 17, 2000. BMP Design Criteria-Appendix B.

Schueler, T.R., Kumble, P.A., and Heraty, M.A. March 1992. A Current Assessment of Urban Best Management Practices: Techniquest for Reducing non-Point Source Pollution in the Coastal Zone.

Schueler, T.R. October 1992. Design of Stormwater Wetland Systems: Guidelines for Creating Diverse and Effective Stormwater Wetlands in the Mid-Atlantic Region.

U.S. Environmental Protection Agency (USEPA). February 1993. Natural Wetlands and Urban Stormwater: Potential Impacts and Management. 